\title{
Budaya Organisasi Memoderasi Pengaruh Adopsi SIA pada Kinerja Organisasi
}

\author{
Julia Yurinne Wahyudi ${ }^{1}$ \\ Fakultas Ekonomi dan Bisnis \\ Universitas Udayana, Indonesia
}

\author{
Dodik Ariyanto ${ }^{2}$ \\ Fakultas Ekonomi dan Bisnis \\ Universitas Udayana, Indonesia
}

\begin{abstract}
Surel : juliayuri14@gmail.com
\section{ABSTRAK}

Penelitian bertujuan untuk mengetahui pengaruh kualitas informasi, kualitas layanan, kualitas sistem terhadap kinerja organisasi dengan budaya organisasi sebagai variable moderasi. Populasi penelitian adalah karyawaan hotel berbintang di Kabupaten Badung yang menggunakan sistem informasi akuntansi berbasis teknologi khususnya bagian akuntansi dan front office. Teknik pengumpulan data yang digunakan adalah sampel jenuh. Dari penyamplingan diperoleh sampel penelitian sebanyak 90 karyawan hotel berbintang di Kabupaten Badung. Teknik analisis data yang digunakan yaitu moderated regression analysis. Hasil penelitian menunjukkan kualitas informasi, kualitas layanan, kualitas system berpengaruh pada kinerja organisasi. Budaya organisasi mampu memperkuat pengaruh kualitas informasi, kualitas layanan, kualitas sistem terhadap kinerja organisasi. Dapat disimpulkan bahwa adopsi teknologi yang diproksikan dengan kinerja organisasi dipengaruhi oleh kualitas informasi, kualitas layanan, kualitas sistem khususnya sistem informasi akuntansi pada hotel.
\end{abstract}

Kata Kunci: Sistem Informasi Akuntansi; Kinerja Organisasi; Budaya Organisasi.

Organizational Culture Moderates the Effect of Accounting Information System Adoption on Organizational Performance

\section{ABSTRACT}

The study aims to determine the effect of information quality, service quality, system quality on organizational performance with organizational culture as a moderating variable. The research population is starred hotel employees in Badung Regency who use technology-based accounting information systems, especially the accounting and front office departments. The data collection technique used is saturated samples. Sampling obtained research samples of 90 star hotel employees in Badung Regency. The data analysis technique used is moderated regression analysis. The results showed that information quality, service quality, system quality had an effect on organizational performance. Organizational culture can strengthen the influence of information quality, service quality, system quality on organizational performance. It can be concluded that the adoption of technology that is proxied by organizational performance is influenced by the quality of information, service quality, system quality, especially accounting information systems in hotels.

Keywords: Accounting Information System; Organizational Performance; Organizational Culture.

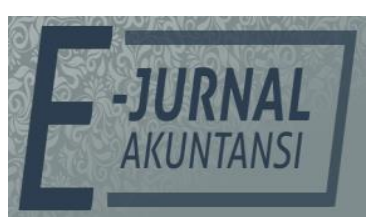

e-ISSN 2302-8556

Vol. 30 No. 8

Denpasar, Agustus 2020

Hal. 2089-2101

DOI:

10.24843/EJA.2020.v30.i08.p15

PENGUTIPAN:

Wahyudi, J. Y. \& Ariyanto, D. (2020). Budaya Organisasi Memoderasi Pengaruh Adopsi SIA pada Kinerja Organisasi. E-Jurnal Akuntansi, 30(8), 2089-2101

RIWAYAT ARTIKEL: Artikel Masuk: 1 Juni 2020 Artikel Diterima: 29 Juli 2020

Artikel dapat diakses : https://ojs.unud.ac.id/index.php/Akuntansi/index 


\section{PENDAHULUAN}

Sitem Informasi Akuntansi (SIA) adalah komponen yang saling berhubungan yang terintegrasi untuk mengumpulkan, menyimpan dan menyebarkan data untuk tujuan perencanaan, pengendalian, koordinasi, analisis dan pengambilan keputusan (Soudani, 2012). SIA penting bagi organisasi ataupun perusahaan guna meningkatkan efisiensi organisasi dan mendukung daya saing perusahaan dengan menyediakan informasi keuangan dan akuntansi bagi manajemen (ALsarayreh, et al., 2011). Pentingnya penggunaan SIA dalam menghasilkan informasi yang berkualitas dalam mendukung proses pengambilan keputusan dapat meningkatkan efisiensi organisasi. SIA yang efekif adalah sistem yang mampu menghasilkan informasi yang berkualitas dan telah sesuai dengan tujuan perusahan dalam penggunaan SIA tersebut.

Pemanfaatan efektivitas sistem informasi akuntansi (SIA) adalah penyebaran luas informasi yang diperlukan oleh berbagai pengguna organisasi. Ini memiliki efek pada pengambilan keputusan dan membantu koordinasi administrasi dalam organisasi. Dengan demikian ditemukan bahwa pengambilan keputusan yang efektif penting untuk kinerja organisasi. Ini pada dasarnya menggambarkan hubungan di antara pemanfaatan sistem informasi Akuntansi dan kinerja organisasi. Dalam hal ini, kualitas layanan, kualitas sistem, kualitas informasi, dan kualitas data ditunjukkan dalam penggunaan sistem informasi akuntansi (Wedyan, et al., 2012). Hotel menggunakan sistem informasi Akuntansi dalam proses menghubungkan layanan industri hotel berdasarkan departemennya karena koneksi yang akan membuatnya dapat diandalkan, menghemat waktu dan juga memuaskan .

Untuk mempermudah perusahaan dalam menjalankan kegiatannya perlu diterapkan sistem informasi akuntansi yang mampu menghasilkan laporan keuangan menjadi informasi yang berguna untuk manajemen dalam mengambil keputusan. Sistem adalah rangkaian dari dua atau lebih komponen-komponen yang saling berhubungan, yang berinteraksi untuk mencapai satu tujuan. Dengan demikian, suatu perusahaan harus membuat perencanaan yang matang sebelum memulai kegiatan operasionalnya untuk meminimalisasi kegagalan yang mungkin terjadi.

Dalam bisnis perhotelan pelayanan merupakan aspek yang sangat penting untuk diperhatikan agar dapat bertahan dan mengembangkan bisnisnya untuk bersaing dengan hotel-hotel berbintang lainnya. Para pelaku bisnis hotel berbintang perlu meningkatkan pelayannya dengan cara meningkatkan kinerja organisasi hotel tersebut. Kinerja organisasi digambarkan sebagai efektivitas dan efisiensi pendekatan kuantifikasi yang meningkatkan produktivitas organisasi (Hyvönen, 2007). Dalam perspektif manajemen bisnis, pengukuran kinerja menunjukkan proses mengukur keefektifan dan efisiensi tindakan bisnis spesifik yang dipandang berkontribusi pada pencapaian tujuan bisnis yang diinginkan (Chan, Chan, \& Qi, 2006) .

Menurut Tripambudi (2014) hubungan antara informasi teknologi, sistem informasi dan budaya organisasi merupakan hubungan antara budaya Informatika dan budaya informasi. (Srite, et.al, 2008) (Ciganek, et al., 2008) menyatakan bahwa nilai suatu budaya akan mempengaruhi karakteristik serta kepercayaan yang berhubungan dengan teknologi informasi. Budaya ini 
menciptakan kohesi di antara para anggota dari suatu organisasi untuk para perancang sistem informasi, maka sistem informasi harus dibuat sedemikian rupa dan diterima sehingga budaya akan menjadi salah satu bagian dari sistem informasi. Sistem informasi tidak semata mengintegrasikan komponen hardware, software, brainware, jaringan komunikasi maupun data base serta prosedur tetapi juga keharmonisan komponen sumber daya manusia yang salah satu bagian penting dengan komponen lainnya didalam suatu sistem informasi (Robey, 1999).

Budaya Organisasi adalah sebuah karakteristik yang dijunjung tinggi oleh organisasi dan menjadi panutan organisasi sebagai pembeda antara satu organisasi dengan organisasi yang lain, (Tika, 2006). Budaya organisasi dikatakan sebagai karakteristik adalah lebih kepada nilai-nilai dan norma perilaku yang disepakati dan dipahami bersama oleh anggota organisasi sebagai dasar dalam aturan berperilaku dalam suatu organisasi. Budaya organisasi juga dapat dijadikan sebagai pembeda dengan organisasi yang lain. Ciri khas atau keunikan yang dapat ditonjolkan yang dapat dijadikan sebagai selling point untuk meningkatkan identitas/brand, citra, dan juga performa/kinerja. Keadaan ini dapat dicapai, ketika seluruh anggota organisasi memahami keseluruhan nilai-nilai organisasi dan menjadikan nilai-nilai tersebut sebagai suatu kepribadian organisasi. Nilai dan keyakinan akan diwujudkan menjadi perilaku keseharian dalam bekerja, sehingga akan menjadi kinerja individual. Jika semua anggota organisasi melaksanakannya, maka kinerja individual itulah yang menjadi awal dari terbentuknya kinerja organisasi.Berdasarkan keterangan dan uraian sebelumnya, pentingnya penggunaan sistem informasi akuntansi dalam mendukung proses pengambilan keputusan dengan menyediakan informasi keuangan dan akuntansi bagi manajemen dapat meningkatkan efisiensi kinerja organisasi. Dalam organisasi tentunya banyak faktor yang memperngaruhi sesorang untuk mencapai tujuannya, sedangkan jalanya organisasi dipengaruhi oleh perilaku banyak individu yang memiliki kepentingan masing-masing. Oleh karena itu, budaya organisasi sangat penting, karena merupakan kebiasaankebiasaan yang ada dalam organisasi. Kebiasaan tersebut mengatur tentang norma- norma prilaku yang harus diikuti oleh para anggota organisasi, sehingga menghasilkan budaya yang produktif. Budaya yang produktif adalah budaya yang dapat menjadikan organisasi menjadi kuat dan tujuan perusahaan dapat tercapai. TAM menjelaskan bahwa ketika ada suatu teknologi baru, maka pemakaian teknologi akan menghadapi faktor-faktor yang mempengaruhi mereka dalam mengunakan teknologi tersebut. Dalam hal ini, kualitas informasi yang tinggi dalam konteks konten informasi (akurasi, kelengkapan, relevansi dengan pengambilan keputusan) dapat menyebabkan dampak kinerja organisasi yang tinggi dalam hal dukungan informasi pasar dan efisiensi organisasi internal (Bharati \& Chaudhury, 2006).

Pemrosesan kualitas sistem informasi mirip dengan pemrosesan produksi dalam organisasi manufaktur. Jika produk (informasi) tidak dikirimkan tepat waktu (ketepatan waktu) dan produk (informasi) tidak sesuai dengan kebutuhan (relevansi) pelanggan (pengguna), maka pelanggan (pengguna) akan tidak puas dan perusahaan akan kehilangan bisnis (Gorla, et al., 2010). Dalam organisasi dihotel kualitas informasi juga diperlukan untuk meningkatkan kinerja 
organisasi. Jika kualitas informasi yang dihasilkan suatus sitem itu baik maka kinerja organiasi dalam hotel tersebut juga baik.Pada peneltian yang dilakukan oleh Soudani (2012) menemukan adanya pengaruh positif pada kualitas informasi.

$\mathrm{H}_{1}$ : Kualitas Informasi berpengaruh positif pada Kinerja Organisasi.

Model TAM meyakini bahwa dalam penggunaan teknologi sistem informasi akan mampu meningkatkan kinerja individu atau organiasi dan penggunannya akan mempermudah pemakaiannya dalam menyelesaikan pekerjaan (Venkatesh et al, 2000). Pemahaman pengaruh kualitas layanan sistem informasi dapat diperoleh dari pengaruh kualitas layanan perusahaan pada kinerja perusahaan. Memberikan kualitas layanan adalah faktor untuk kesuksesan bisnis yang mengarah pada loyalitas pelanggan, profitabilitas yang lebih besar, mengurangi biaya. Kesuma et al., (2013) (Kesuma, et al., 2013) menyatakan bahwa kualitas layanan yang luar biasa membantu dalam menghasilkan pendapatan yang lebih baik yang secara bertahap menghasilkan keuntungan yang lebih besar. Dalam hal ini, jika kualitas layanan sebuah sistem baik, maka kinerja yang dihasilkan dari organisasi pun akan mengahsilkan kinerja yang baik pula.

Pada peneltian yang dilakukan oleh (Weerakoon \& Wijavanayake, 2013) menemukan adanya pengaruh positif pada kualitas layanan.

$\mathrm{H}_{2}$ : Kualitas Layanan berpengaruh pada Kinerja Organisasi.

TAM dibangun untuk menjelaskan bagaimana pengguna atau user dapat menerima suatu teknologi dalam sistem informasi. TAM juga merinci faktor faktor apa saja yang dapat mempengaruhi penerimaan suatu teknologi dalam sistem informasi tersebut. Kualitas sistem dapat mempengaruhi penggunaan, kepuasan pengguna dan kinerja individu, dan akibatnya mempengaruhi kinerja organisasi (Petter, et al., 2008). Prasyarat penting untuk menghasilkan manfaat organisasi adalah sistem yang dirancang, dikembangkan, dan diimplementasikan dengan baik (Ali, et al., 2016) Di sisi lain, sistem yang tidak dirancang dan dibangun dengan baik kemungkinan akan mengalami crash sistem sesekali, yang merupakan merugikan operasi bisnis akibatnya menyebabkan peningkatan biaya produk perusahaan (Swanson, 1997).

Secara umum, hubungan antara kualitas sistem dan manfaat bersih telah didokumentasikan sedikit oleh literatur. Meskipun hubungan antara kemudahan penggunaan dirasakan sebagai ukuran kualitas sistem dan manfaat yang dirasakan memiliki hasil yang bervariasi. Sebagian besar penelitian melaporkan bahwa kualitas sistem berpengaruh positif dengan manfaat organisasi seperti (Marlita, 2014), dan (Dina, 2014).

$\mathrm{H}_{3}$ : Kualitas Sistem berpengaruh positif pada Kinerja Organisasi.

Kualitas informasi menunjukkan kualitas produk yang dihasilkan oleh aplikasi sistem dan informasinya akan mempunyai pengaruh pada pemakai dan sistemnya (Dewi, et al., 2019) Kualitas informasi yang baik, yang direpresentasikan dari output sistem yang diperoleh yang dapat berpengaruh pada kepuasan pengguna. Kualitas informasi yang dihasilkan sistem menjadi langkah awal sebuah hotell mengambil tindakan organisasi dan proses pengambilan keputusan diinstruksikan oleh budaya organisasi, sehingga mendukung kesejahteraan organisasi. Di sisi lain, budaya organisasi dapat 
dianggap sebagai praktik manajemen sumber daya manusia, atau praktik manajerial yang sering memengaruhi dewan perusahaan, pemegang saham, atau preferensi pemangku kepentingan lainnya. Dari penjelasan, maka hipotesis yang dapat dirumuskan adalah sebagai berikut.

$\mathrm{H}_{4}$ : Budaya organisasi memperkuat pengaruh kualitas informasi terhadap kinerja organisasi.

Budaya organisasi merupakan suatu kespakatan bersama para anggota dalam suatu organisasi atau perusahaan sehingga mempermudah lahirnya kesepakatan yang lebih luas untuk kepentingan perorangan. Keutamaan budaya organisasi merupakan pengendali dan arah dalam membentuk sikap dan perilaku manusia yang melibatkan diri dalam suatu kegiatan organisasi. Secara individu maupun kelompok seseorang tidak akan terlepas dengan budaya organisasi dan pada umumnya mereka akan dipengaruhi oleh keaneka ragaman sumber-sumber daya yang ada sebagai stimulus seseorang bertindak. Dalam studi Babulak, (2006) kinerja kerja disebut sebagai diciptakan oleh karyawan individu di tempat kerja. Faktor pribadi yang mempengaruhi kinerja adalah pengetahuan, kemampuan, keterampilan, motivasi dan sikap. Mekanisme transisi yang membantu menghasilkan hasil kinerja yang lebih baik di tempat kerja adalah sistem manajemen kinerja, interaksi dengan kolega dan atasan, tujuan kinerja yang pasti, dorongan perusahaan, dan tindakan atau rencana penghargaan dalam mengenali kinerja yang luar biasa. Dalam hal ini, jika kualitas layanan suatu sistem bekerja dengan baik maka kinerja organiasi yang didukung dengan budaya organisasi yang baik maka menghasilkan hasil yang baik pula.

$\mathrm{H}_{5}$ : Budaya organisasi memperkuat pengaruh kualitas layanan terhadap kinerja organisasi.

Berbagai tindakan yang dilakukan oleh seseorang tentunya berbeda-beda dalam bentuk perilakunya. Dalam organisasi implementasi budaya dirupakan dalam bentuk perilaku artinya perilaku individu dalam organisasi akan diwarnai oleh budaya organisasi yang bersangkutan. (Arnold \& Fieldman, 1986) perilaku individu berkenaan dengan tindakan yang nyata dilakukan oleh seseorang dapat diartikan bahwa dalam melakukan tindakan seseorang pasti akan tidak terlepas dari perilakunya. Jika kinerja atau tindakan individu seorang karyawan baik maka kinerja dalam organisasinya bisa dikatakan baik. Dalam hal ini didukung dengan kualitas sistem yang memadai dalam sebuah organisasi, maka hasil yang didapatkan nanti menjadi baik.

$\mathrm{H}_{6}$ : Budaya organisasi memperkuat pengaruh kualitas sistem terhadap kinerja organisasi.

\section{METODE PENELITIAN}

Dalam penelitian ini terdiri dari satu variabel terikat dan tiga variabel bebas. Kinerja karyawan merupakan variabel terikat dalam penelitian ini, sedangkan pengendalian internm presepsi pemanfaatan sistem informasi akuntansi, dan komitmen organisasi merupakan variabel bebas.

Penelitian ini dilakukan pada hotel bintang lima yang terdapat di Kabupaten Badung. Obyek pada penelitiani ini adalah kinerja organisasi dari hotel bintang lima yang terletak di Kabupaten Badung. Populasi dalam 
penelitian ini adalah karyawan akuntansi hotel bintang lima yang terdapat di Kabupaten Badung. Teknik penentuan sampel pada penelitian ini adalah dengan menggunakan menggunakan simple random sampling. Teknik pengumpulan sampel yang digunakan adalah metode random sampling. Kriteria yang digunakan menentukan sampel dalam penelitian ini adalah karyawan bagian akuntansi hotel bintang 5 yang terletak di Kabupaten Badung sebanyak 30 hotel dan yang sebagai sampel penelitian sebanyak 90 orang.

Instrumen penelitian digunakan untuk mengukur nilai variabel yang diteliti, atau dalam penelitian ini adalah variabel sistem informasi dimana Kualitas Informasi (X1), Kualitas Layanan (X2), Kualitas Sistem (X3), Budaya Organisasi (X4), dan Kinerja Organisasi (Y). Setiap instrumen harus memiliki skala, dalam penelitian ini, skala yang digunakan adalah skala Likert.Penelitian ini menggunakan teknik analisis regresi linear bergdanda dan teknik analisis reggresi moderasi. Analisis regresi berganda digunakan untuk pengolahan dengan bantuap program SPSS for Windows. Teknik analisis regresi moderasi digunakan untuk menguji variabel moderasi, dimana MRA merupakan aplikasi khusus regresi yang dalam persamaan regresinya mengandung unsur interaksi perkalian dua atau lebih variabel independen. Adapun persamaan regresi yang dihasilkan dari model regresi dalam penelitian ini, yaitu:

Keterangan

$$
Y=\alpha+\beta_{1} X_{1}+\beta_{2} X_{2}+\beta_{3} X_{3}+\beta_{4} X_{4}+\beta_{5} X_{1} X_{4}+\beta_{6} X_{2} X_{4}+\beta_{7} X_{3} X_{4}+\varepsilon
$$

$$
\begin{array}{ll}
\mathrm{Y} & =\text { Kinerja Organisasi } \\
\mathrm{a} & =\text { Konstanta } \\
\beta_{1}-\beta_{6}=\text { Koefisien Regresi } \\
\mathrm{X}_{1}=\text { Kualitas Informasi } \\
\mathrm{X}_{2} \quad=\text { Kualitas Layanan } \\
\mathrm{X}_{3}=\text { Kualitas Sistem } \\
\mathrm{X}_{4} \quad=\text { Budaya Organisasi } \\
\mathrm{X}_{1} \mathrm{X}_{4}=\text { Interaksi antara Kualitas Informasi dengan Budaya Organisasi } \\
\mathrm{X}_{2} \mathrm{X}_{4} & =\text { Interaksi antara Kualitas Layanan dengan Budaya Organisasi } \\
\mathrm{X}_{3} \mathrm{X}_{4} & =\text { Interaksi antara Kualitas Sistem dengan Budaya Organisasi } \\
\varepsilon & =\text { Standar error }
\end{array}
$$

\section{HASIL DAN PEMBAHASAN}

Analisis statistik deskriptif yaitu analisis yang menguraikan tentang faktor-faktor yang berpengaruh pada kinerja organisais yang terjadi dilapangan untuk memperoleh gambaran yang jelas dan objektif tentang hasil penelitian. Setiap jawaban kusioner mempunyai bobot atau skor nilai dengan Skala Likert sebagai berikut: skor 4 untuk jawaban sangat setuju dengan kode SS, skor 3 untuk jawaban setuju dengan kode $S$, skor 2 untuk jawaban tidak setuju dengan kode TS, skor 1 untuk jawaban sangat tidak setuju dengan kode STS. Hasil statistic deskriptif dapat dilihat pada Tabel 1.

Variabel kinerja organisasi (Y) menggunakan indikator efektivitas dan efisiensi, otoritas dan tanggungjawab, disiplin, dan inisiatif yang berjumlah 7 pertanyaan. Variabel kinerja organisasi memiliki nilai minimum sebesar 1 dan nilai maksimum sebesar 4 dengan nilai rata - rata sejumlah 2.773. Nilai standar deviasi pada variabel kinerja organisasi (Y) sebesar 1.760. Statistik deskriptif 
dalam penelitian ini menunjukkan rata - rata skor jawaban variabel Y lebih besar dari standar devisiasi yang artinya sebaran data berdistribusi normal, sehingga dapat disimpulkan dari 90 responden sebagian besar menyetujui pertanyaan pertanyaan yang diajukan dalam kusioner yang berarti kinerja organisasi dalam hotel tersebut berjalan dengan baik.

Tabel 1. Hasil Statistik Deskriptif Variabel Penelitian

\begin{tabular}{llllll}
\hline & $N$ & Minimum & Maximum & Mean & Std. Deviation \\
\hline Kualitas Informasi (X1) & 90 & 1 & 4 & 3.217 & 1.957 \\
Kualitas Layanan (X2) & 90 & 1 & 4 & 3.142 & 1.368 \\
Kualitas Sistem (X3) & 90 & 1 & 4 & 3.224 & 1.413 \\
Budaya Organisasi (X4) & 90 & 1 & 4 & 3.823 & 2.362 \\
Kinerja Organisasi (Y) & 90 & 1 & 4 & 2.773 & 1.760 \\
Valid N (listwise) & 90 & & & &
\end{tabular}

Sumber: Data Penelitian, 2020

Variabel kualitas informasi $\left(\mathrm{X}_{1}\right)$ menggunakan indikator completeness, personalization, dan relevance yang berjumalah 6 pertanyaan. Variabel kualitas informasi memiliki nilai minimum 1 dan nilai maskimum 4 dengan nilai rata rata sejumlah 3.217. Nilai standar deviasi pada variabel kualitas informasi $\left(\mathrm{X}_{1}\right)$ sebesar 1.957. Statistik deskriptif dalam penelitian ini menunjukkan rata - rata skor jawaban variabel $\mathrm{X}_{1}$ lebih besar dari standar deviasi yang artinya sebaran data berdistribusi normal, sehingga dapat disimpulkan dari 90 responden sebagian besar menyetujui pertanyaan - pertanyaan yang diajukan dalam kusioner yang berarti kualitas informasi yang dihasilkan adalah lengkap.

Variabel kualitas layanan $\left(\mathrm{X}_{2}\right)$ menggunakan indikator responsiveness, assurance, dan responsive yang berjumlah 5 pertanyaan. Variabel kualitas layanan memiliki nilai minimum 1 dan nilai maksimum 4 dengan nilai rata - rata sejumlah 3.224. Nilai standar deviasi pada variabel kulaitas layanan $\left(X_{2}\right)$ sebesar 1.368. Statistik deskriptif dalam penelitian ini menunjukkan rata - rata skor jawaban variabel $\mathrm{X}_{2}$ lebih besar dari standar deviasi yang artinya sebaran data berdistribusi normal, sehingga dapat disimpulkan dari 90 respoden sebagian besar menyetujui pertanyaan - pertanyaan yang diajakukan dalam kusioner yang berarti kulitas layanan sudah menjamin kepuasan pelanggan.

Variabel kualitas sistem $\left(X_{3}\right)$ menggunakan indikator adaptability, realibility, dan response time yang berjumlah 5 pertanyaan. Variabel kualitas sistem memiliki nilai minimum 4 dan nilai maksimum 4 dengan nilai rata - rata sejumlah 3.224. Nilai standar deviasi pada variabel kualitas sistem $\left(\mathrm{X}_{3}\right)$ sebesar 1.413. Statistik deskriptif dalam penelitian ini menunjukkan rata - rata skor jawaban variabel $X_{3}$ lebih besar dari standar deviasi yang artinya sebaran data berdistribusi normal, sehingga dapat disimpulkan dari 90 responden sebagian besar menyetujui pertanyaan - pertanyaan yang diajukan dalam kuesioner yang berarti kualitas sistem memiliki keandalan yang baik.

Variabel budaya organisasi $\left(\mathrm{X}_{4}\right)$ menggunakan indikator innovation and risk taking, attentiom to detail, outcome orientation, people orientation, team orientation, 
aggressiveness, dan stability yang berjumlah 7 pertanyaan. Variabel budaya organisasi memiliki nilai minimum 1 dan nilai maksimum sebesar 4 dengan nilai rata - rata sejumlah 3.823. Nilai standar deviasi pada variabel budaya organisasi $\left(\mathrm{X}_{4}\right)$ sebesar 2.362. Statistik deskriptif dalam penelitian ini menunjukkan rata rata skor jawaban variabel $\mathrm{X}_{4}$ lebih besar dari standar deviasi yanga artinya sebaran dara berdistribusi normal, dapat disimpulkan dari 90 responden sebagian besar menyetujui pertanyaan - pertanyaan yang diajukkan dalam kusioner yang berarti karyawan memiliki orientasi budaya organisai yang baik.

Tabel 2. Hasil Uji Analisis Regresi Linier Berganda

\begin{tabular}{|c|c|c|c|c|c|}
\hline \multirow[t]{2}{*}{ Model } & \multirow{2}{*}{$\begin{array}{l}\text { Unstandardized } \\
\text { Coefficients } \\
\text { B }\end{array}$} & \multicolumn{2}{|c|}{$\begin{array}{l}\text { Standardized } \\
\text { Coefficients }\end{array}$} & \multirow[b]{2}{*}{$\mathrm{T}$} & \multirow[b]{2}{*}{ Sig. } \\
\hline & & Std. Error & Beta & & \\
\hline (Constant) & 6.180 & 2.060 & & 3.001 & 0,004 \\
\hline Kualitas Informasi $\left(\mathrm{X}_{1}\right)$ & 0,332 & 0,115 & 0,369 & 2.894 & 0,005 \\
\hline Kualitas Layanan $\left(\mathrm{X}_{2}\right)$ & 0,319 & 0,132 & 0,315 & 2.142 & 0,007 \\
\hline Kualitas Sistem $\left(X_{3}\right)$ & 0,341 & 0,147 & 0,273 & 2.320 & 0,023 \\
\hline $\begin{array}{l}\text { Budaya } \\
\left(\mathrm{X}_{4}\right)\end{array}$ & 0,271 & 0,084 & 0,295 & 2.003 & 0,031 \\
\hline$X_{1} \cdot X_{4}$ & 0,166 & 0,080 & 0,236 & 2.082 & 0,041 \\
\hline$X_{2} \cdot X_{4}$ & 0,418 & 0,099 & 0,421 & 4.224 & 0,000 \\
\hline$X_{3} . X_{4}$ & 0,348 & 0,151 & 0,244 & 2.299 & 0,025 \\
\hline R Square & & & & & 0,583 \\
\hline Adjusted R Square & & & & & 0,564 \\
\hline F Hitung & & & & & 16,855 \\
\hline Signifikasni F & & & & & 0,000 \\
\hline
\end{tabular}

Sumber: Data Penelitian, 2020 berikut:

Berdasarkan Tabel 2, maka dapat disusun persamaan regresi sebagai

$$
Y=6,180+0,332 X_{1}+0,319 X_{2}+0,341 X_{3}+0,217 X_{4}+0,166 X_{1} X_{4}+0,418 X_{2} X_{4}+0,348 X_{3} X_{4}
$$

Pada Tabel 2, dapat dilihat bahwa hasil analisis pengaruh kualitas informasi terhadap kinerja organisasi diperoleh nilai signifikansi sebesar 0,005 dengan nilai koefisien regresi beta sebesar 0,332. Nilai Signifikansi 0,005 $<0,05$ mengindikasikan bahwa $\mathrm{H}_{0}$ ditolak dan $\mathrm{H}_{1}$ dterima. Hasil ini mempunyai arti bahwa kualitas informasi berpengaruh positif dan signifikan terhadap kinerja organisasi.

Hasil penelitian ini menujukkan bahwa variabel kualitas informasi berpengaruh positif pada kinerja organisasi, dimana kualitas informasi merupakan faktor penting untuk meningkatkan kinerja organisasi. Temuan dari data empiris menunjukkan bahwa organisasi dapat meningkatkan kinerja mereka secara keseluruhan dengan informasi yang berkualitas. Hal itu terjadi karena kualitas informasi menyebabkan pengurangan kegiatan biaya operasi yang berada di luar sistem pemrosesan informasi. Kualitas informasi yang tinggi dalam konteks informasi (akurasi, kelengkapan, relevansi dengan pengambilan keputusan) dapat menyebabkan dampak organisasi yang baik dalam hal dukungan informasi pasar seperti mengantisipasi kebutuhan pelanggan dan efisiensi organisasi internal yang akibatnya mengarah pada kinerja organiasasi yang lebih baik. 
TAM menjelaskan bahwa ketika ada suatu teknologi baru, maka pemakaian teknologi akan menghadapi faktor-faktor yang mempengaruhi mereka dalam mengunakan teknologi tersebut. Dalam hal ini, kualitas informasi yang tinggi dalam konteks konten informasi (akurasi, kelengkapan, relevansi dengan pengambilan keputusan) dapat menyebabkan dampak kinerja organisasi yang tinggi dalam hal dukungan informasi pasar dan efisiensi organisasi internal (Bharati \& Chaudhury, 2006). Penelitian ini sejalan dengan penelitian yang dilakukan oleh (Soudani, 2012) menunjukkan bawaha kualitas layanan berpengaruh positif terhadap kinerja organiasi.

Pada Tabel 2, dapat dilihat bahwa hasil analisis pengaruh kualitas layanan terhadap kinerja organisasi diperoleh nilai signifikan sebesar 0,007 dengan nilai koefisien regresi beta sebesar 0,319. Nilai signifikansi $0,007<0,05$ mengindikasikan bahwa $\mathrm{H}_{0}$ ditolak dan $\mathrm{H}_{2}$ diterima. Hasil ini mempunyai arti bahwa kualitas layanan mempunyai arti bahwa kualitas layanan berpengaruh positif dan signifikan terhadap kinerja organisasi.

Hasil penelitian ini menunjukkan bahwa variabel kualitas layanan berpengaruh positif pada kinerja organisasi, dimana mengukur kualitas layanan dapat membantu manajemen memberikan informasi yang dapat diandalkan dan digunakan untuk mengamati dan menjaga kualitas layanan sehingga kualitas layanan yang diberikan semakin baik untuk kedepannya. Kualitas layanan memungkinkan manajemen untuk lebih memahami berbagai aspek dan cara untuk memuaskan pelanggan.

Model TAM meyakini bahwa dalam penggunaan teknologi sistem informasi akan mampu meningkatkan kinerja individu atau organiasi dan penggunannya akan mempermudah pemakaiannya dalam menyelesaikan pekerjaan (Venkatesh et al, 2000). Pemahaman pengaruh kualitas layanan sistem informasi dapat diperoleh dari pengaruh kualitas layanan perusahaan pada kinerja perusahaan. Memberikan kualitas layanan adalah faktor untuk kesuksesan bisnis yang mengarah pada loyalitas pelanggan, profitabilitas yang lebih besar, mengurangi biaya. Penelitian ini sejalan dengan penelitian yang dilakukan oleh (Weerakoon \& Wijavanayake, 2013), menunjukkan bawa kualitas layanan berpengaruh positif terhadap kinerja organisasi.

Pada Tabel 2, dapat dilihat bahwa hasil analisis pengaruh kualitas sistem terhadap kinerja organisasi diperoleh nilai signifikansi sebesar 0,023 dengan nilai koefisien regresi beta sebesar 0,341. Nilai signifikansi 0,023 $<0,05$ mengindikasikan bahwa $\mathrm{H}_{0}$ ditolak dan $\mathrm{H}_{3}$ diterima. Hasil ini mempunyai arti bahwa kualitas sistem berpengaruh positif dan signifikan terhadap kinerja organisasi.

Hasil penelitian ini menunjukkan bahwa variabel kualitas sistem berpengaruh positif pada kinerja organisasi, dimana kualitas sistem dapat mempengaruhi penggunaan, kepuasan pengguna dan kinerja organiasai. Kualitas sistem merupakan faktor penting untuk kelangsungan hidup organisasi di dunia global saat ini. Prasyarat yang diperlukan untuk mengarahkan manfaat organisasi adalah sistem yang dirancang, dikembangkan, dan diimplementasikan dengan baik yang memainkan peran penting untuk menjalankan organisasi dengan benar dan meningkatkan kinerja. 
TAM dibangun untuk menjelaskan bagaimana pengguna atau user dapat menerima suatu teknologi dalam sistem informasi. TAM juga merinci faktor faktor apa saja yang dapat mempengaruhi penerimaan suatu teknologi dalam sistem informasi tersebut. Kualitas sistem dapat mempengaruhi penggunaan, kepuasan pengguna dan kinerja individu, dan akibatnya mempengaruhi kinerja organisasi. Penelitian ini sejalan dengan penelitian yang dilakukan oleh (Hsieh \& Wang, 2007), menunjukkan bawaha kualitas istem berpengaruh terhadap kinerja organisasi.

Berdasarkan hasil analisis regresi moderasi pada Tabel 2, diketahui bahwa interaksi antara variabel kualitas informasi dan kinerja organisasi yang dimoderasi oleh budaya organisasi memiliki nilai koefisien beta positif sebesar 0,166 dengan nilai signifikansi sebesar 0,041 . Nilai koefisien beta $>0$ dan nilai signifikansi $<0,05$ mengindikasikan bahwa budaya organisasi mampu memoderasi dengan memperkuat pengaruh kualitas informasi terhadap kinerja organisasi. Dengan demikian, $\mathrm{H}_{4}$ diterima.

Hasil penelitian ini menunjukkan bahwa budaya organisasi mampu memoderasi pengaruh kualitas informasi pada kinereja organisasi, dimana mengenai perilaku seseorang yang ditentukan oleh sikap yang terkait dengan apa yang orang- orang ingin lakukan serta terdiri dari keyakinan mengenai konsekuensi dari melakukan perilaku, aturan-aturan sosial yang terkait dengan apa yang mereka pikirkan akan mereka, dan kebiasaan yang terkait dengan apa yang mereka biasa lakukan. Hal ini merupakan salah satu wujud dari budaya organisasi mengenai sikap dan perilaku seseorang terhadap suatu teknologi sistem informasi. Dengan budaya organisasi tersubut maka kualitas informasi yang dihasilkan menjadi informasi yang bias baik dan bias dipertanggungjawabkan.

Dalam TAM, kualitas informasi menunjukkan kualitas produk yang dihasilkan oleh aplikasi sistem dan informasinya akan mempunyai pengaruh pada pemakai dan sistemnya. Kualitas informasi yang baik, yang direpresentasikan dari output sistem yang diperoleh yang dapat berpengaruh pada kepuasan pengguna. Kualitas informasi yang dihasilkan sistem menjadi langkah awal sebuah hotel mengambil tindakan organisasi dan proses pengambilan keputusan diinstruksikan oleh budaya organisasi, sehingga mendukung kesejahteraan organisasi.

Berdasarkan hasil analisis regresi moderasi pada Tabel 2, diketahui bahwa interaksi antara variabel kualitas layanan dan kinerja organisasi yang dimoderasi oleh budaya organisasi memiliki nilai koefisien beta positif sebesar 0,418 dengan nilai signifikansi sebesar 0,000. Nilai koefisien beta $>0$ dan nilai signifikansi < 0,05 mengindikasikan bahwa budaya organisasi mampu memoderasi dengan memperkuat pengaruh kualitas layanan terhadap kinerja organisasi. Dengan demikian, $\mathrm{H}_{5}$ diterima.

Hasil penelitian ini menunjukkan bahwa budaya organisasi mampu memoderasi pengaruh kualitas layanan pada kinerja organisasi, dimana budya organisasi juga dapat menjadi instrument keunggulan kompetitif utama, yaitu budaya organiasasi mendukung strategi organisasi dan budaya organisasi dapat menjawab atau mengatasi lingkungan dengan cepat dan tepat. Dengan budaya organisasi tersebut kualitas layanan yang dihasilkan akan baik dan memuaskan 
para pelanggan. TAM mengakui bahwa tidak ada ukuran kualitas layanan tertentu yang mapan, dan menyarankan bahwa ukuran kualitas layanan yang dapat diandalkan harus mencakup langkah-langkah seperti responsif dan kompetensi teknis. Dalam model yang diusulkan, kualitas layanan dikonseptualisasikan sebagai kualitas dukungan yang diterima pengguna.

Berdasarkan hasil analisis regresi moderasi pada Tabel 2, diketahui bahwa interaksi antara variabel kualitas sistem dan kinerja organisasi yang dimoderasi oleh budaya organisasi memiliki nilai koefisien beta positif sebesar 0,348 dengan nilai signifikansi sebesar 0,025 . Nilai koefisien beta $>0$ dan nilai signifikansi $<$ 0,05 mengindikasikan bahwa budaya organisasi mampu memoderasi dengan memperkuat pengaruh kualitas sistem terhadap kinerja organisasi. Dengan demikian, $\mathrm{H}_{6}$ diterima.

Hasil penelitian ini menunjukkan bahwa budaya organisasi mampu memoderasi kualitas sistem pada kinerja organisasi, dimana budaya organisasi memumbuhkan sikap positif terhadap diri karyawan karena sikap positif tersebut membuat orang tidak mudah mengeluh dan menyerah. Dengan demikian karyawan akan memilhat masalah yang terjadi dalam sistem tersebut sebagai tantangan dan peluang, sehingga kualitas sistem yang dihasikan nanti akan mudah dipahami oleh karyawan tersebut. TAM meyakini bahwa dalam penggunaan teknologi sistem informasi akan mampu meningkatkan kinerja individu atau organisasi, dan penggunaannya akan memermudah pemakainya dalam menyelesaikan suatu pekerjaan.

Koefisien determinasi $\left(\mathrm{R}^{2}\right)$ digunakan untuk mengetahui dan mengukur kemampuan model dalam menerangkan variasi variabel independen. Pada penelitian ini menggunakan nilai adjusted $\mathrm{R}^{2}$ pada saat mengevaluasi yang mana model regresi terbaik, karena tidak seperti $\mathrm{R}^{2}$, nilai adjusted $\mathrm{R}^{2}$ dapat naik atau turun apabila satu variabel independen ditambahkan ke dalam model. Hasil uji memberikan hasil dimana diperoleh besarnya adjusted $\mathrm{R}^{2}$ (koefisien determinasi yang telah disesuikan) adalah 0.564 . Ini berarti sebesar 56,4 persen variasi kinerja organisasi dipengaruhi oleh kualitas informasi, kualitas layanan, kualitas sistem dan budaya organisasi sebagai pemoderasi sedangkan sisanya sebesar 43,6 persen dipengaruhi oleh faktor lain yang tidak dimaksukkan ke dalam model penelitian.

Uji keterandalan model atau uji kelayakan model atau yang lebih popular disebut sebagai uji $\mathrm{F}$ merupakan tahapan awal mengidentifikasi model regresi yang diestimasi layak atau tidak. Layak (andal) disini maksudnya adalah model yang diestimasi layak digunakan untuk mejelazskan pengaruh variabel variabel bebas terhadap variabel terikat. Sig. Tabel ANOVA menunjukkan besarnya angka probabilitas atau signifikansi pada perhitungan ANOVA. Nilai yang tertera digunakan untuk uji kelayanan Model Analisis (dimana sejumlah variabel $x$ mempengaruhi variabel y) dengan ketentuan angka probabilitas yang baik untuk digunakan sebgai model regresi harus $<0.05$. Nilai ini bias dilihat pada kolom Sig. Jika signifikasnsi < 0.05, maka Moel Analisis dianggap layak. Jika nilai signifikansi $>0.05$, maka Model Analisis dianggap tidak layak.

Hasil uji $F$ (Ftest) menunjukkan bahwa nilai signifikansi $P$ value 0,000 yang lebih kecil dari $\alpha=0,05$, ini berarti model yang digunakan penelitian ini 
adalah layak. Hasil ini memberikan bahwa seluruh variable independen mampu memprediksi atau menjelaskan fenomena kinerja organisasi.

\section{SIMPULAN}

Hasil penelitian ini dapat memberikan kontribusi mengenai pengaruh kualitas informasi, kualitas layanan dan kualitas sistem pada kinerja organisasi dengan budaya organiassi sebagai pemoderasi. Hasil uji penelitian ini menunjukkan searah dengan kinerja organiasi yang dimiliki hotel, sedangkan budaya organiasai sebagai pemoderasi menunjukkan mampu memoderasi pengaruh kualitas informasi, kualitas layanan dan kualitas sistem yang dimiliki organisasi. Hasil penelitian ini mampu memberikan implikasi pada pihak hotel guna meningkatkan sistem akuntansi yang ada di hotel bintang 5 di Kabupaten Badung, yang dimana tidak hanya berfokus pada pengetahuan tentang hotel namun juga menekanakan pentingnya implementasi dari pengetahuan yang membuat karyawan memiliki kinerja yang bertanggung jawab dan berkompeten sehingga menggasilkan kinerja organisaisi yang lebih baik kedepannya dan pelanggan puas dengan hasil yang diberikan oleh kinerja tersebut.

\section{REFERENSI}

Ali, B. J. A., Wan, W. A., \& Bakar, R. (2016). Effect of ICT on Accounting Information System and Organizational Performance. European Law Review, 4(4), 138-158. https:// doi.org/10.21859/eulawrev-08061

ALsarayreh, M. N., Jawabreh, O. A. A., Jaradat, M. M. F., \& ALamro, S. A. (2011). Technological impacts on effectiveness of accounting information systems (AIS) applied by Aqaba tourist hotels. European Journal of Scientific Research, 59(3), 361-369.

Arnold, \& Fieldman. (1986). Organitasional behaviour.

Babulak, E. (2006). Quality of service provision assessment in the healthcare information and telecommunications infrastructures. International Journal of Medical Informatics, 75(3-4 SPEC. ISS.), 246-252. https:// doi.org/10.1016/j.ijmedinf.2005.07.019

Bharati, P., \& Chaudhury, A. (2006). Product customization on the web: An empirical study of factors impacting choiceboard user satisfaction. Information Resources Management Journal, 19(2), 69-81. https:// doi.org/10.4018/irmj.2006040105

Chan, F. T. S., Chan, H. K., \& Qi, H. J. (2006). A review of performance measurement systems for supply chain management. International Journal of Business Performance Management, 8(2-3), 110-131. https:// doi.org/10.1504/IJBPM.2006.009032

Ciganek, A. P., Mao, E., \& Srite, M. (2008). Organizational culture for knowledge management systems: A study of corporate users. Selected Readings on Information Technology Management: Contemporary Issues, 4(1), 441-456. https:// doi.org/10.4018/978-1-60566-092-9.ch024

Dewi, N. F., Ferdous Azam, S. M., \& Yusoff, S. K. M. (2019). Factors influencing the information quality of local government financial statement and financial accountability. Management Science Letters, 9(9), 1373-1384. https:// doi.org/10.5267/j.msl.2019.5.013 
Dina. (2014). Pengaruh Sistem Informasi Akuntansi Dan Motivasi Terhadap Kinerja Pada Perusahaan Retail Di Pekanbaru. Skripsi. Fakultas Ekonomi Unversitas Riau. Riau.

Gorla, N., Somers, T. M., \& Wong, B. (2010). Organizational impact of system quality, information quality, and service quality. Journal of Strategic Information Systems, 19(3), 207-228. https:// doi.org/10.1016/j.jsis.2010.05.001

Hyvönen, J. (2007). Strategy, performance measurement techniques and information technology of the firm and their links to organizational performance. Management Accounting Research, 18(3), 343-366. https:/ / doi.org/10.1016/j.mar.2007.02.001

Kesuma, I., Hadiwidjojo, D., Wiagustini, N., \& Rohman, F. (2013). Service Quality Influence on Patient Loyalty: Customer Relationship Management as Mediation Variable (Study on Private Hospital Industry in Denpasar). International Journal of Business and Commerce, 2(12), 1-14.

Marlita. (2014). Pengaruh Penerapan Sistem Informasi Dan Pemanfaatan Terhadap Kinerja Karyawan.

Petter, S., DeLone, W., \& McLean, E. (2008). Measuring information systems success: Models, dimensions, measures, and interrelationships. European Journal of Information Systems, 17(3), 236-263. https:// doi.org/10.1057/ejis.2008.15

Robey, D. (1999). Learning failure in information systems development. Information Systems Journal, 9(2), 85-101. https://doi.org/10.1046/j.13652575.1999.00051.x

Soudani, S. N. (2012). The Usefulness of an Accounting Information System for Effective Organizational Performance. International Journal of Economics and Finance, 4(5), 136-145. https:// doi.org/10.5539/ijef.v4n5p136

Swanson, E. B. (1997). Maintaining IS quality. Information and Software Technology, 39(12), 845-850. https:/ / doi.org/10.1016/S0950-5849(97)00043-8

Tika. (2006). Budaya Organisasi dan Peningkatan Kinerja Organisasi. Jakarta: Bumi aksara.

Venkatesh, V., \& Davis, F. D. (2000). Theoretical extension of the Technology Acceptance Model: Four longitudinal field studies. Management Science, 46(2), 186-204. https:// doi.org/10.1287/mnsc.46.2.186.11926

Wedyan, L. M. A.-R., Gharaibeh, A. T. S., Abu-dawleh, A. I. M., \& Abu Hamatta, H. S. (2012). The Affect of Applying Accounting Information System on the Profitability of Commercial Banks in Jordan. Journal of Management Research, 4(2). https:/ / doi.org/10.5296/jmr.v4i2.1427

Weerakoon, W. M. L. P., \& Wijavanayake, W. M. J. (2013). Impact of the information systems service quality on performance of IT sector organizations in sri lanka. International Conference on Advances in ICT for Emerging Regions, ICTer 2013 - Conference Proceedings, 84-91. https://doi.org/10.1109/ICTer.2013.6761160 